татом исследования проблемы является значимость статистической взаимосвязи психологической дезадаптации и сексуальной неудовлетворенности. Это значит, что психологическое состояние человека оказывает огромное влияние на сексуальную жизнь и наоборот, сексуальная сфера человеческой жизни обеспечивает определенное наполнение и общее психическое фоновое состояние личности в любих жизненных ситуациях.

Ключевые слова: личность, психологическая дезадаптация, сексуальность, сексуальная неудовлетворенность, адаптационные возможности.

I. Norkina, postgraduate student

Taras Shevchenko National University of Kyiv, Kyiv

\title{
PSYCHOLOGICAL DISADAPTATION AS A CAUSE OF DISSATISFACTION WITH SEXUAL LIFE
}

The article presents the view on the problem of psychological maladaptation as a factor of dissatisfaction with sexual life, which is manifested in the disclosure of the data of the concepts, descriptions and characteristic features that are manifested in these concepts. The psychological aspects of the manifestation of psychological maladaptation and sexual dissatisfaction are revealed, and an empirical study of the relationship between psychological maladaptation and sexual dissatisfaction was conducted. Sexual and psychological relationships are caused by a determinant relationship (have their internal causes and external effects), this in turn indicates that sex life has an impact on interpersonal, intimate relationships among partners, and can also serve as a cause of the psychological defining of the individual. An important aspect was the sexual satisfaction with its physiological and psychological components, and the special role of various manifestations of feelings (mood, anxiety, emotions, stresses) on the sexual function of the individual was proved. The result of the study is the significance of the statistical relationship between psychological maladaptation and sexual dissatisfaction. This means that the psychological state of a person has a great influence on sexual life and vice versa, the sexual sphere of human life provides a certain amount of filling and general mental background state of personality in any life situations. With the help of theoretical and empirical analysis we received the following results: high indicators of sexual satisfaction and realized evidence of the ability of a person to feel pleasure during sexual intercourse, to control their own sexual behavior In accordance with the norms of social and personal ethics. Such a person is free of fear, a sense of shame and guilt, false representations and other psychological factors that inhibit sexual response and violate sexual relations.

Keywords: personality, psychological maladaptation, sexuality, sexual dissatisfaction, adaptive possibilities.

Bulletin of Taras Shevchenko National University of Kyiv.

Series "Psychology". № 2(9), pp. 56-60 (2018)

УДК 159.937+159.9.072+159.922.7

DOI: https://doi.org/10.17721/BSP.2018.2(9).14
ISSN $1728-3817$

(c) Taras Shevchenko National University of Kyiv,

Publishing Center "Kyiv University", 2018

Н. Погорільська, канд. психол. наук, доц., Ю. Маціонова, студ. Київський національний університет імені Тараса Шевченка, Київ

\section{ОСОБЛИВОСТІ СПРИЙМАННЯ ЧАСУ ПІДЛІТКАМИ В КОНТЕКСТІ ЇХНЬОÏ ЖИТТЕВОÏ АКТИВНОСТІ}

Визначається зв'язок між індивідуальними особливостями сприймання часу і рівнями життєвої активності особистості. Проаналізовано вітчизняні й зарубіжні теоретичні підходи, емпіричні дослідження понять часової орієнтації особистості та життєвої активності зокрема. На основі проведеного емпіричного дослідження розкрито особливості часової орієнтацї̈ особистості підліткового віку та фактори, які впливають на формування точності вимірювання часу.

Ключові слова: психологічний час, часова орієнтація, життєва активність, особливості підліткового віку, психічний стан особистості, типологія акцентуацій характеру.

Постановка проблеми. У рамках психологічної науки накопичено величезну кількість фрактів про проблему часу, яка має вкрай різнобічний характер. Хоча проблема дослідження часу в психології достатньо відома, особливості сприймання часу в контексті життєвої активності особистості підліткового віку залишається відкритою. Саме тому ця робота спрямована на розкриття основних закономірностей вияву сприймання часу підлітками залежно від їх життєвої активності.

Незважаючи на те, що деякими вченими робилось припущення про наявність відмінностей у сприйманні часу залежно від життєвої активності особистості (напр., О. І. Цукановим [5, с. 14], А. М. Козловою, К. О. Абульхановою), сучасна молодь, на думку провідних соціологів, уважається новою генерацією. Це, у першу чергу, пов'язано з інформатизацією суспільства. Тому $є$ необхідність вивчення особливостей сприймання часу в контексті сучасності, зокрема у сучасних підлітків.

Отримані результати дозволяють говорити про різноманітні рівні сприймання часу в психіці підлітків, від вроджених біологічних циклів до складного суб'єктивного відчуття прожитого часу. Це, з одного боку, дає основу для зняття протиріччя між невизначеністю часу як фрізичного об'єкту, який протиставлений суб'єкту. Окрім того, аналіз фракторів, що впливають на сприймання часу, дає можливість здійснити прогноз соціально-психологічного розвитку особистості, зрозуміти її регулятивні можливості в умовах прискореного соціального життя.

Стаття має за мету дослідити особливості сприймання часу підлітками на різноманітних рівнях психічного відображення, починаючи від елементарного сприймання і закінчуючи організацією цілісної діяльності в часі.

Із розглянутих теорій розуміння часу, найбільш точним поняттям $€$ визначення часу як спрямованої величини (вектора), однозначне визначення якого передбачає не тільки систему одиниць вимірювання (секунда, хвилина, година, доба, місяць, рік, століття), але й постійну відправну точку, від якої ведеться рахунок [1, с. 61]. Час можна розглядати у двох варіантах: у першому випадку - як показник нашої життєвої активності, в іншому - ії обмежувач. Хоча у будь-якому підході час являє собою певний ресурс, яким людина вчиться розпоряджатись упродовж життя.

Уявлення про час вибудовуються поступово як в окремої людини, так і у людства в цілому [6, с. 56]. Часові категорії визначаються культурою (або цивілізацією), парадигми якої задовольняються в індивідуальній та колективній свідомості. Ідея часу психологічно офрормилася із двох різних джерел повторюваності та неповторюваності подій, тобто ритмічного повторення чогось (ударів пульсу, добової зміни дня і ночі, сезонів року) і неповторного однократного плину чогось, наприклад народження, зростання, старіння й умирання живих істот [4, с. 46].

Розглядаючи як об'єкт безпосередньо переживаючу тривалість, спиратимемось на положення про те, що час $€$ реальністю, яка відкривається людині в сукупності його метричних і топологічних властивостей. Ці властивості багато в чому визначаються матеріальним органом людини - мозком, який виконує роль її власного годинника.

(๐) Погорільська Н., Маціонова Ю., 2018 
Не важко припустити, що в безпосередньо пережитій індивідом тривалості існує власна одиниця часу, тому дане міркування підкріплюється поглядами інших дослідників, наприклад, Є.І. Головахою [3, с. 84], О. О. Кроніком, С. Л. Рубінштейном, Б.І.Цукановим. Щодо особливостей сприймання часу людьми, важливе значення матиме класифрікація, запропонована Б.І. Цукановим, відповідно до якої люди поділяються на тих, хто поспішає, повільних та тих, точно сприймає час.

Хоча, як ми бачимо, на основі розглянутих джерел особливості сприймання часу вже досліджувались, однак особливості сприймання часу в контексті життєвої активності людини в сучасних підлітків залишається актуальним.

Таким чином предметом дослідження виступають особливості сприймання часу підлітками у контексті їх життєвої активності. Для реалізації даної мети було залучено 60 підлітків (23 хлопчики та 37 дівчаток) у віці від 12 до 15 років, які навчаються у 8 та 9 класі загальноосвітньої школи I-III ступенів. Так, для визначення точності сприймання часу застосували такі методики:

- методику відмірювання хвилинного інтервалу досліджуваному необхідно виміряти хвилину, рахуючи до 60 і пропускаючи між кожним відліком секунду;

- методику визначення хвилини без всякого рахунку (тільки на основі відчуття часу) - для цього пропонується прочитати довільний фррагмент із тексту;

- тест Франкенхойзера - проговорювання однієї цифри за одну секунду.

Застосовуючи методику М. О. Курганського, опитувальник О. О. Зворикіна та методику "Психологічна автобіографрія" (О. Ю. Коржова, Л. Ф. Бурлачук), змогли визначити рівень активності та життєву орієнтацію підлітків.

Методика М. О. Курганського призначена для визначення особливостей психічного стану людини за показниками психічної активації, інтересу, емоційного тонусу, напруження й комфортності. За допомогою методики
О. О. Зворикіна "Особистісний комплексний соціометричний тест" дослідили тип акцентуації характеру підлітків в умовах сучасного освітнього закладу. Розпізнавання типу акцентуацій у першу чергу пов'язано з особливостями даного вікового періоду. Методика "Психологічна автобіографія" застосована для оцінки ситуаційних особливостей життєвого шляху особистості та дозволяє виявити особливості сприймання значущих життєвих ситуацій, а саме - найважливіших подій у житті людини. Загалом було використано саме ці методики, оскільки при дослідженні точності виміру часових інтервалів за їхнею допомогою ми можемо визначити чинники впливу на процес оцінки.

Виклад результатів дослідження. За особливостями сприймання часу, на основі запропонованої Б. І. Цукановим класифікації, досліджувані були розділені на три групи: 1) ті, хто поспішають, при оцінці часових інтервалів; 2) точно сприймають; 3) недооцінюють заданий проміжок часу. За результатами проведеного дослідження сучасні підлітки належать переважно до поспішаючого типу. При чому, неточність в одній сфрері тягне за собою спотворення і в інших: "точні" підлітки мають вищий рівень життєвої активності та є більш адекватними в оцінці інших аспектів реальності, включаючи складові Я-концепції (когнітивну, оцінну і поведінкову).

Окрім того, досліджувані з високим рівнем життєвої активності схильні сприймати часовий інтервал як більш короткий $(0,75)$, порівняно 3 досліджуваними із середнім рівнем життєвої активності $(0,91)$. Тому можна зробити припущення, що вони оцінюють час як більш швидкоплинний, коли вони зайняті якоюсь діяльністю.

Порівняльний аналіз виявив статистично значущу різницю між показниками "істеричні риси" та "інтерес" між показниками у групах із середнім та високим рівнем життєвої активності. При чому в групі із середнім рівнем життєвої активності ці показники вищі: інтерес - 10,81; істеричні риси - 9,35 (рис. 1)

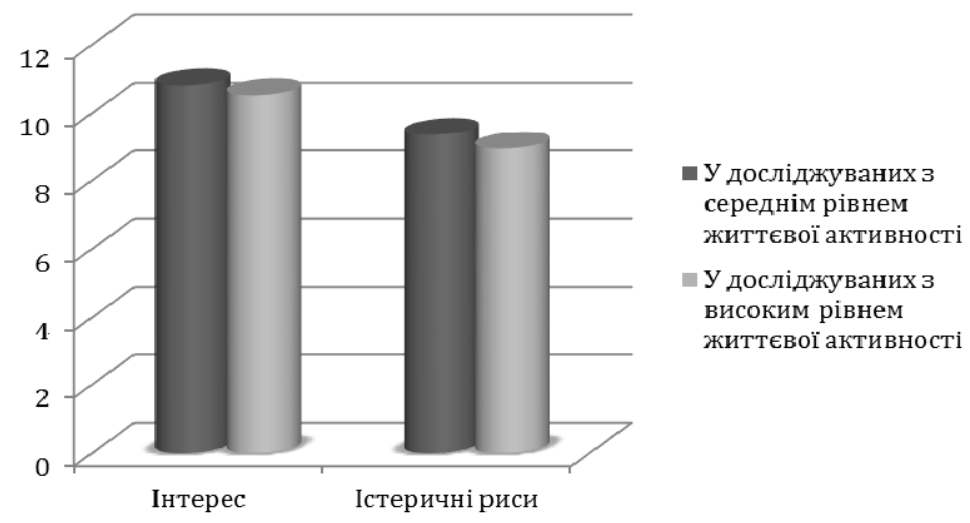

Рис. 1. Порівняльний аналіз істеричних рис та інтересу в досліджуваних із середнім та високим рівнем життєвої активності

Показник "істеричні риси" указує на те, що в групі із середнім рівнем життєвої активності підлітки трошки більше схильні, ніж у групі з високим рівнем життєвої активності, до привернення уваги з боку інших до своєї персони, потреби викликати в оточуючих подив, захоплення, співчуття та шанування. Окрім того, більш високий рівень інтересу теж пов'язаний із виявом істероїдних рис, оскільки методика М.О.Курганського, яка призначена для визначення психічних станів особистості, будується на самозвіті (семантичному диференціалі, тобто досліджувані оцінюють себе такими).
Відповідно до типів акцентуації характеру, які були визначені за допомогою опитувальника О. О. Зворикіна (рис. 2), бачимо що найбільш характерне домінування епітимних рис $(9,71)$ та рис афективної нестабільності $(9,73)$ у підлітків із високим рівнем життєвої активності. Під першими розуміється прагнення до влади, акуратність у дрібницях, педантичність у дотриманні правил (навіть не на користь справі), добре адаптуються до нових умов. Для афективно-нестабільного типу характерна висока мінливість настрою. Їм подобаються компанії, вони шукають нових вражень у новому оточенні. 


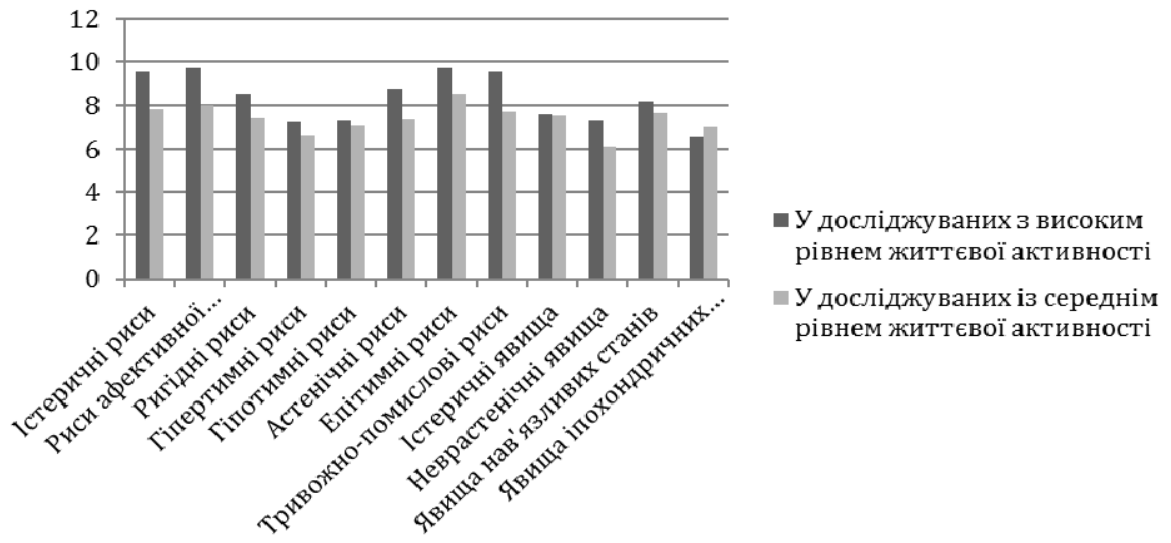

Рис. 2. Усереднені показники типів акцентуації характеру в досліджуваних із середнім та високим рівнем життєвої активності

У підлітків із середнім рівнем життєвої активності домінують такі самі акцентуації: епітимні риси $(8,56)$ та риси ефективної нестабільності $(8,05)$. Переважання таких рис також може бути пояснене особливостями даного вікового періоду [2, с. 5], оскільки підлітки, вийшовши з дитячого віку і перебуваючи на сходинці нового життя, прагнуть якнайшвидше стати дорослими, хочуть порвати із жорстким батьківським контролем та стати самостійними.

За допомогою методики О.Ю. Коржової та Л. Ф. Бурлачука, помітили, що підлітки, зазначаючи майбутні та минулі подій, орієнтуються на спогади, що пов'язані з особистісними та соціальними змінами. При чому для досліджуваних із середнім рівнем життєвої активності на перший план виступають особистісні зміни, а з високим рівнем життєвої активності - соціальні зміни (рис. 3). I це не є дивним, тому що саме на межі підліткового та юнацького віку виявляється відношення до самовизначення, яке формується і включається в Я-концепцію. Особистісне самовизначення задає особистісно значущу орієнтацію на досягнення певного рівня у системі соціальних відносин, тобто задає соціальне самовизначення.

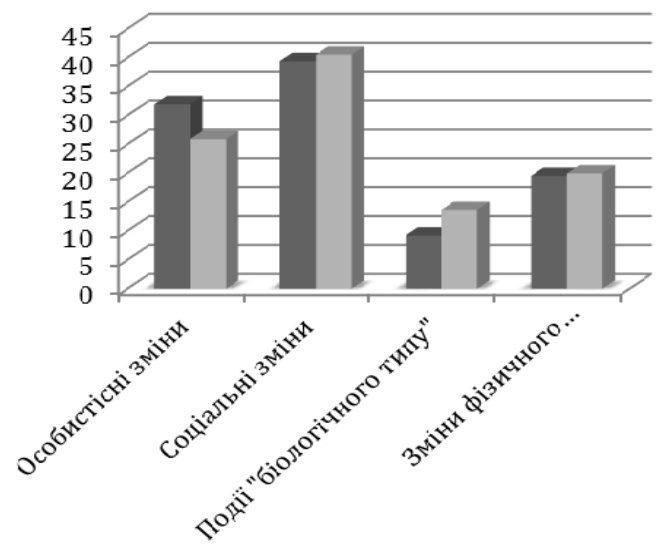

\footnotetext{
-У досліджуваних 3 середнім рівнем життєвої активності

- У досліджуваних з високим рівнем
} життєвої активності

Рис. 3. Порівняльний аналіз спогадів у досліджуваних із середнім та високим рівнем життєвої активності

Деякі дослідники, наприклад Н.Г. Черепанова. М. Р. Кулешева, Є. Ю. Балашова, П. А. Хенкок, уважають, що існують відмінності у сприйманні часу залежно від статі. Так, чоловіки точніше оцінюють тривалі відрізки часу, а жінки - коротші проміжки часу. Тому є потреба перевірити дану гіпотезу 3 огляду на наші результати. Оскільки в нашому досліджені чоловіків було менше, ніж жінок, для вирівнювання вибірок випадковим чином (рандомно) було зменшено вибірку жінок на п'ять осіб. Із отриманих показників побачили, що немає різниці між сприйманням часу в чоловіків та жінок, оскільки $p>0,05$ (табл. 1).

Було здійснено кореляційний аналіз між рівнем життєвої активності досліджуваного та типом сприймання часу (табл. 2).

Було виявлено прямий (сила зв'язку середня) зв'язок між рівнем життєвої активності та типом сприймання часу - кореляція значуща на рівні 0,05. Тобто чим вищий рівень життєвої активності має досліджуваний, тим швидше він оцінюватиме пройдений часовий інтервал.
Також перевірили, чи існує відмінність при оцінці часового інтервалу залежно від психічного стану особистості для групи із середнім рівнем життєвої активності. Було виявлено зворотний (сила зв'язку висока) зв'язок між психічною активацією та результатами тесту Франкенхойзера, при чому кореляція значуща на рівні 0,01 (табл. 3). Підлітки, які оцінюють себе як більш утомлені (ситуативно), витрачають більше часу на проговорювання чисел.

У групі з високим рівнем життєвої активності було виявлено два зв'язки: прямий середній зв'язок між ригідними рисами та тестом Франкенхойзера $(0,45)$ (кореляція значуща на рівні 0,01) та зворотній середній - між комфортністю та вимірюванням хвилинного інтервалу $(-, 414)$ - кореляція значуща на рівні 0,05 (табл. 4).

Досліджувані з високим рівнем життєвої активності більше часу витрачають на проговорювання чисел, якщо в них є ригідні риси (особистісна властивість); і переоцінюють хвилинний інтервал в стані дискомфорту (ситуативно). 


\begin{tabular}{|c|c|}
\hline \hline \multicolumn{2}{|c|}{ Статеві особливості сприймання часу } \\
\hline Методика & \multicolumn{2}{|c}{ Асимпт. 3нач. (двостороння) } \\
\hline Вимірювання хвилинного інтервалу & 0,527 \\
\hline Визначення хвилини без рахунку & 0,073 \\
\hline Тест Франкенхойзера & 0,864 \\
\hline
\end{tabular}

таблиця 2

Кореляційний аналіз між рівнем життєвої активності досліджуваного та типом сприймання часу

\begin{tabular}{|l|l|c|}
\hline & & Тип сприймання часу \\
\hline Рівень життєвої активності & Коефіцієнт кореляції & 0,416 \\
\hline
\end{tabular}

Кореляційний аналіз між сприйманням часу та психічним станом

таблиця 3 для групи із середнім рівнем життєвої активності

\begin{tabular}{|l|l|c|}
\hline \multicolumn{2}{|c|}{ для групи із середнім рівнем життєвої активності } & Психічна активація \\
\hline Тест Франкенхойзера & Кореляція Пірсона & $-0,677$ \\
\hline
\end{tabular}

Кореляційний аналіз між сприйманням часу, психічним станом та типом акцентуації для групи із високим рівнем життєвої активності

\begin{tabular}{|l|l|c|}
\hline \multicolumn{1}{|c|}{ та типом акцентуації для групи із високим рівнем життєої активності } & \multicolumn{1}{|c|}{ Комфортність } & Ригідні риси \\
\hline Тест Франкенхойзера & Кореляція Пірсона & 0,450 \\
\hline Вимірювання хвилинного інтервалу & Кореляція Пірсона & $-0,414$ \\
\hline
\end{tabular}

Висновки. У результаті проведеного емпіричного дослідження було визначено, що сучасні підлітки мають високий рівень життєвої активності, що виявляється у підвищених інтересі, демонстративності та, навіть, істеричності поведінки.

У цілому, можна стверджувати, що чим більше подій називає досліджуваний, тим вища його загальна продуктивність, що характеризує, як правило, багатство психологічного часу, тобто багатство і легкість актуалізації образів минулого та майбутнього, а також адекватність психічного стану й соціальну адаптованість.

Переважна більшість підлітків належить до типу тих, хто поспішає, і орієнтовані на минулі події, зокрема на ті, які пов'язані із соціальними та особистісними змінами. При цьому позитивні, емоційно яскраві враження запам'ятовуються досліджуваними найбільше.

На основі теоретичних та емпіричних джерел було виокремлено такі ймовірні фрактори сприймання часу: індивідуально-типологічні особливості досліджуваних (вік, стать, властивості пам'яті, сприймання, домінуючий настрій, його знак, тип і рівень вираженості, рухливість, ригідність, комфортність, самооцінка, вживання медикаментів та інших засобів, які впливають на ритміку організму) і соціально психологічні умови (складність діяльності, образ життя). Окрім того, на переживання людиною часу впливають внутрішні відчуття та відчуття віку: на скільки людина себе почуває, який вік здається їй продуктивним, насиченим. У рамках проведеного дослідження було підтверджено вплив тільки ригідності та комфортності (і лише для групи осіб із високим рівнем життєвої активності). При чому ригідність збільшує тривалість проговорювання чисел, а особи з високим рівнем життєвої активності точніше оцінюють часовий інтервал.

Для корекційної роботи з адекватного сприймання часу потрібно враховувати стан утоми, дискомфорту підлітків та такі особистісні риси, як ригідність. Так, утому та дискомфорт можна подолати за допомогою гарно організованих умов та психогімнастичних вправ, а 3 ригідністю працювати важче.
Перспективи дослідження полягають у подальшому вивченні психологічних чинників особливостей сприймання часу в різних категорій осіб. Логічним і актуальним видається створення психологічних програм для різного контингенту осіб.

\section{Список використаних джерел}

1. Арестова О.Н. Операциональные аспекты временной перспективы личности / О. Н. Арестова // Вопросы психологии. - 2000. - № 4. C. $61-74$.

2. Балашова Е. Ю. Возрастные различия в восприятии и переживании времени / Е. Ю. Балашова, Л. И. Микеладзе //Психология зрелости и старения: ежекварт. науч.-практ. журн. / ред. О. В.Краснова. - 2006. - С. 5-24.

3. Головаха Е. И. Психологическое время личности / Е. И. Головаха, А. А. Кроник. - К. : Наукова думка, 1984. - С. 84-110.

4. Полунін О. В. Психологічні механізми часової організації життєвого досвіду індивіда / О. В. Полунін. - К. : Центр учбової літератури, 2011. С. $46-50,70-101$

5. Цуканов Б.И. Время в психике человека/Б. И. Цуканов. Одесса : Изд-во "АстроПринт", 2000. - С. 14-34, 167-181.

6. Элькин Д. Г. Оценка длительности временных интервалов в условиях дефицита времени / Д. Г. Элькин // Новые исследования в психологии. - М., 1976. - Вып. 2. - С. 56-59.

7. Zimbardo P. Putting Time in Perspective: A Valid, Reliable Individual Difference Metric / P. Zimbardo \& J. Boyd // The journal of Personality and Social Psychology. - 1999. - P. 1271-1288.

Reference

1. Arestova O. N. Operatsionalnye aspekty vremennol perspektivy lichnosti/ O. N. Arestova // Voprosy psikhologii. - 2000. - № 4. - S. 61-74.

2. Balashova E. lu. Vozrastnye razlichiia $v$ vospriiatie $i$ perezhivanii vremeni / E. Iu. Balashova, L. I. Mikeladze // Psikhologiia zrelosti i stareniia: ezhekvartalnyi nauchno-prakticheskii zhurnal/ Red. O. V. Krasnova. 2006. - S. 5-24.

3. Golovakha E. I. Psikhologicheskoe vremia lichnosti / E. I. Golovakha, A. A. Kronik. - K. : Naukova dumka, 1984. - S. 84-110.

4. Polunin O. V. Psykholohichni mekhanizmy chasovoi orhanizatsii zhyttievoho dosvidu indyvida / O. V. Polunin. - K.: Tsentr uchbovoi literatury, 2011. - S. 46-50, 70-101.

5. Tsukanov B. I. Vremia v psikhike cheloveka / B. I. Tsukanov. Odessa : Izd-vo "AstroPrint", 2000. - S. 14-34, 167-181.

6. Elkin D. G. Otsenka dlitelnosti vremennykh intervalov $v$ usloviiakh defitsita vremeni / D. G. Elkin // Novye issledovaniia $\vee$ psikhologii. - M., 1976, vyp. 2. - S. 56-59.

7. Zimbardo P. Putting Time in Perspective: A Valid, Reliable Individual Difference Metric / P. Zimbardo \& J. Boyd / The journal of Personality and Social Psychology. - 1999. - P. 1271-1288.

Надійшла до редколегії 14.10.18

Н. Погорельская, канд. психол. наук, доц.,

Ю. Мационова, студ.

Киевский национальный университет имени Тараса Шевченко, Киев

\section{ОСОБЕННОСТИ ВОСПРИЯТИЯ ВРЕМЕНИ ПОДРОСТКАМИ В КОНТЕКСТЕ ИХ ЖИЗНЕННОЙ АКТИВНОСТИ}

Определяется связь между индивидуальными особенностями восприятия времени и уровнями жизненной активности личности. Проанализированы отечественные и зарубежные теоретические подходы, эмпирические исследования понятий временной ориента- 
ции личности и жизненной активности в частности. На основе проведенного эмпирического исследования раскрыты особенности временной ориентации личности подросткового возраста и факторы, влияющие на формирование точности измерения времени.

Ключевые слова: психологическое время, временная ориентация, жизненная активность, особенности подросткового возраста, психическое состояние личности, типология акцентуаций характера.

N. Pogoril'ska, Ph. D., Assoc. Prof.,

Yu. Matsionova, student

Taras Shevchenko National University of Kyiv, Kyiv

\section{FEATURES OF ADOLESCENTS TIME PERCEPTION IN THE CONTEXT OF THEIR LIVING ACTIVITY}

The article defines the connection between the individual peculiarities of time perception and the levels of personal life activity. The results of the empirical study suggest that the diversity of levels in the perception of time in the adolescent psyche depends on a number of factors, including innate biological cycles $t$, ending with a complex subjective sense of time (in the context of age-related changes). Accordingly, it eliminates the contradiction between the uncertainties of the opposing time of the subject. Theoretical analysis of the factors that determine the perception of a teenager's personality provides an opportunity to make a prediction in social and psychological development in the context of accelerated social life. From the considered theories of understanding of time, the most comprehensive concept in the context of adolescent life activity is the definition of time as a directed value (vector), the unambiguous definition of which implies not only a system of units of measure (second, minute, hour, day, month, year, century), but and the constant starting point from which the account is maintained. The article made a comparative analysis of hysterical traits of the subjects with middle and high activity level of life, as well as the analysis of memories of adolescents with medium and high level of life activity. On the basis of the empirical research the features of time orientation of adolescence personality are revealed and factors that influence the formation of time measurement accuracy. The domestic and foreign theoretical approaches, empirical researches of concepts of the time orientation of the personality and vital activity in particular are analyzed. On the basis of the empirical research, features of the age orientation of the adolescent age and factors influencing the formation of the accuracy of time measurement are revealed.

Keywords: psychological time, time orientation, vital activity, peculiarities of adolescence, psychic state of personality, typology of character accentuations.

Bulletin of Taras Shevchenko National University of Kyiv. Series "Psychology". № 2(9), pp. 60-63 (2018) УДК 159.922.1:355

DOI: https://doi.org/10.17721/BSP.2018.2(9).15
ISSN 1728-3817

(C) Taras Shevchenko National University of Kyiv,

Publishing Center "Kyiv University", 2018

М. Прищепа, психолог Збройні Сили України

\section{ГЕНДЕРНІ ОСОБЛИВОСТІ ПЕРЕЖИВАННЯ ПСИХОТРАВМУЮЧИХ СИТУАЦІЙ ВІЙСЬКОВОСЛУЖБОВЦЯМИ В ХОДІ РЕСОЦІАЛІЗАЦІЇ В ПОСТТРАВМАТИЧНИЙ ПЕРІОД}

Присвячено аналізу відмінностей у сприйманні стресових і психотравмуючих ситуацій та їх впливу на особистісні зміни між чоловіками й жінками, які брали участь у бойових діях і які перебували поза зоною військового конфлікту в період ресоціалізації.

Ключові слова: військовослужбовець, посттравматичний стресовий розлад, психотравмуюча ситуація, стресостійкість, бойові дї.

Актуальність дослідження. У світі сьогоднішніх трагічних подій в Україні поряд із економічною кризою, військовими діями, окупацією Криму й Донбасу військами Російської Федерації, загостренням політичної ситуації, доволі актуальною темою сьогодення $€$ подолання психічних травм, стресових, гострих стресових та посттравматичних стресових розладів (ПТСР). Ураховуючи соціально-політичну ситуацію у країні, вплив на свідомість людей агресивного інформаційного чинника та наслідків бойових дій на території України гостро випливає проблема ресоціалізації військовослужбовців у посттравматичний період, а саме в період адаптації після повернення із зони бойових дій, переживання стресових станів, бойового стресу.

Аналіз останніх досліджень і публікацій. На сьогодні 3 гендерної проблематики опубліковано вже доволі багато наукових праць, які містять, переважно, переклади зарубіжних і вітчизняних класиків із фемінізму та гендерних досліджень, таких, як: М. Сігел, Д. Батлер, О. Бурчак, Л. Кобелянська, Р. Брайдотті, Т. де Лауретіс тощо.

Метою статті $є$ виявлення гендерних особливостей переживання психотравмуючих ситуацій у ході ресоціалізації в посттравматичний період.

Виклад основного матеріалу дослідження. На основі аналізу екстремальних, емоційно складних, критичних, кризових ситуацій було розроблено класифікацію рівнів психотравмуючих ситуацій, вивчення переживань у травмуючих ситуаціях різних рівнів такими дослідниками, як Е. Носенко, Ф. Василюк, О. Саннікова, І. Маноха, Г. Сельє, Т. Титаренко, Л. Сохань, Є. Головаха, В. Очеретяний та багатьма іншими. Водночас, не було охоплено дослідження бага- тьох інших проблем, таких, як: відмінність у сприйманні стресових і психотравмуючих ситуацій та їх вплив на особистісні зміни між чоловіками й жінками, які брали участь у бойових діях та які перебували поза зоною військового конфрлікту. Тому ми взяли за мету дослідити саме ці питання.

Традиційно травми розрізняють:

- за видом травмуючого фактора (людина, природа);

- за терміном дії травмуючого фактора (гострі, хронічні);

- за обставинами, за яких травма виникає (катастрофа, сім'я, спорт, воєнні дії тощо).

Щодо виявів реакцій на стрес, ураховуючі саме гендерний аспект, С. Бем у своїй монографії "Лінзи тендеру" (1993), розглядає поширену думку і віру, що відмінності в поведінці чоловіків і жінок, їхні соціальні позиції є наслідком біологічних, тобто статевих відмінностей.

Для успішної ресоціалізації військових у мирне життя потрібно дотримуватись ряду вимог. Сюди входить і вибір методів та технік психокорекційної роботи, які визначають враховуючи індивідуально-психологічні особливості кожного індивіда та головні завдання психологічної корекції:

- зниження емоційного напруження;

- відновлення функціонального стану організму;

- навчання основним методам психічної саморегуляції;

- підвищення особистісного адаптаційного потенціалу;

- відновлення моральних рис особистості військовослужбовців;

- фрормування конструктивного стереотипу поведінки, який би сприяв подальшим успіхам у професійній сфері та особистому житті;

- розвиток комунікативних здібностей і навичок. 